\title{
Discontinuities and Discrepancies in the Hybridization Process of Nangnang Culture
}

\author{
Andrea de Benedittis*
}

\section{Introduction}

This article marks an attempt to approach one of the most controversial topics in ancient Korean history, Nangnang, in order to find an alternative narrative that can explain some processes in the development of this territory from the point of view of the local people. The tendency to label and consider Nangnang merely as a "Han commandery" risks transmitting a distorted picture of the evolution of its local culture, inasmuch as the expression "Han commandery" itself appears to be obsolete and inadequate at capturing what this complex society was. It is likely that a community or even a kingdom called "Nangnang" existed well before the Han invasion, ${ }^{1}$ and the migratory flow of people from other regions of the continent led to the progressive remodeling of local culture and institutions and embedded them in a more international network. The same phenomenon also occurred in areas that were not under the direct control of the Han Empire.

The best efforts at this sort of approach to Nangnang's history until

* University of Naples "L'Orientale"

1 See Kim, Nam-jung, "Wiman Chosŏn-ŭi 1segi ijŏn Nangnang chiyŏk-ŭi tae-han yŏrŏ insik" [The Various Awareness for the Fall of Wiman Joseon and Nakrang Area before the First Century], Han'guk sahakpo 70 (2018): 76. 
now can be credited to Pai Hyung Il (2000), ${ }^{2}$ who tried to reevaluate the cultural legacy of the "commandery" in the broader context of early Northeast Asian civilization. ${ }^{3}$ In her book Constructing Korean Origins, she offers an alternative explanation for the problem, applying acculturation theory to Nangnang. In this article, we will focus more on the analysis of "discontinuities" and "discrepancies" in Nangnang's history to better reconstruct the evolution of its past. More specifically, we take inspiration from the approach of Edward Said and his concept of "discrepant experience," which proposed to explore different narratives of the past, not just those based on the historical accounts of the victors. In this attempt, we also argue that it is unrealistic to interpret Nangnang's history within uninterrupted continuity boundaries, but rather, we should consider it as a succession of rifts, adjustments, and continuous modulations. In fact, accounts tend to vastly oversimplify some crucial problems to project an idea of uniformity and linearity. In this article, as the title indicates, I will also adopt the word "hybridization"-referring to the opening and contamination of Nangnang culture by continental trends-instead of "Hanization" — as this word would imply a unilateral and irreversible process of acculturation and influence from China, which erroneously transmits the idea of a progressive and unidirectional replacement of local culture and customs. Hybridization, which also includes that of material culture, can be a consequence of various factors, for example, objects traded from other territories may have inspired artisans to incorporate

2 Pai Hyung Il, Constructing "Korean" Origins (Cambridge: Harvard-Hallym, 2000).

3 Yingzi Xu, "Lelang Cultural Interaction Sphere: An 'Alternative' Approach to State-Formation in Korea," International Journal of Korean History 2 (December 2001): 352.

4 I use here the term 'Hanization' which is a translation of the concept hanhwa (漢化) (which refers more specifically to Han Empire or Han ethnicity), as I find it more it pertinent than a more general "sinicization", even if this is much more common. A hypothetical expression constructed on the term Central plain (Zhongyuan) could be philologically more correct, but it is not used as far in the current literature. 
stylistic features that originated far away ${ }^{5}$. This term translates the idea of a cultural syncretism, more than a process of imposition of norms and cultural aspects over a non-Han population. Especially after the establishment of the Han Empire, the construction of long-distance communication systems and the resettlement of people in different territories for military or economical purposes created the conditions for a larger and stronger circulation of ideas and objects, and the culture of Nangnang region reflects these syncretistic qualities ${ }^{6}$.

\section{Preliminary remarks}

For a period of 423 years, beginning with the installation of the "four Han commanderies" from $109 \mathrm{BC}$ to AD 314, part of the territory of the northwestern Korean peninsula-which also encompasses the P'yŏngyang area—was under the political or at least cultural influence of external, nonlocal communities. This is basically what we know primarily from Chinese written sources. Wang proposes to call this significantly long phase of Northeast Asian history the "Period of the Nangnang Commandery,"

5 We prefer here the word 'hybridization' to 'creolization' or other similar terms as it translated better the idea of a contamination of tastes and trends in a not colonial context. Standing to the definition of 'creolization' by Françoise Vergès 'it occurred under a situation of severe constraints, under the yoke of slavery, colonialism and racism, in situations of deep inequalities, of forced circumstance and of survival strategies." See Vergès, F., Creolization and Resistance. Creolizing Europe. Liverpool : Liverpool University Press : 42.

6 Altaweel, M., and Squitieri, A. Revolutionizing a World. London : UCL Press, 187.

7 Bei Xin Wang, Lelang Wenhua [Nangnang Culture] (Beijing: Kexue chubanshe, 2007), 2. In this article, we prefer the Korean reading "Nangnang" over the Chinese "Lelang," first of all because the use of the term "Lelang" itself implies origins in Chinese culture; however, before lending its name to the commandery, Nangnang was a toponym, and the name - unrelated to the role the territory would later play-likely existed even before the Han Empire. "Every third day of the 
influential of these "four Han commanderies." This phase of hypothetical external interference can potentially be extended another eighty-five years, from 194 to $109 \mathrm{BC}$, to include the period in which Wiman (c. Wei Man) was designated a 'foreign vassal' by the Han dynasty. ${ }^{8}$ In addition, Yi notes that several titles and official positions (such as Nangnanggong, Nangnang kungong, Nangnang kunwang, Nangnang t'aesu, Nangnang wang) were conferred by the Chinese court as symbols of prestige and authority even after the fall of these commanderies; ${ }^{9}$ this means that, at least partially, this phase of influence lasted beyond the year $314 .{ }^{10}$ This period exerted a strong cultural influence on Korea until at least AD 661 and, paradoxically, this long phase of proto-Korean history is almost comparable in chronological extent to both the history of Koryŏ (474 years) and that of Chosonn (505 years); however, on the basis of its archaeological remains, it is hard to ascribe to Nangnang a narrative found-

third month, in Koguryŏ, [people] gathered on the hill of Nangnang." 高句麗常以三月三日會獵樂浪之丘. Moreover, there is a reference to Nangnang-do, a road in Nangnang, in Samguk Sagi v. 24, Ǔlchi Mundǒk.

8 There are two main theories on the origins of Wei Man and the nature of his reign: one claims that he was an indigenous person, from Chosonn, and the other, that he was an ethnic Chinese, the leader of a Han group. See, for example, O-jung Kwŏn, "Nangnanggun-ŭi sŏlch'i paegyŏng" [The Background of the Installation of Nangnanggun], Sejong Taehak nonmunjip, 1984, 204. In the Records of the Grand Historian, it is said he was 'originally from Yan' (Records of the Grand Historian, 115: The account of Chaoxian).

9 We find these titles, for example, in several passages of the Samguk Sagi: in volume 5, we find the expression Nangnang kungong (柱國樂浪郡公新羅王) in a passage related to the year AD 651. In a passage from book 6, we read that in 662, King Munmu was recognized as Nangnang Silla Wang (開府儀同三司上柱國樂浪 郡王新羅王” 。帶方郡王 百濟王), y. 605 Samguk Sagi v. 27, Kim Mu, y. 25. We also find the expression Nangnang king (樂浪王) in Samguk Sagi v. 14, King Taemusin, y. 15.

10 Sŏng-si Yi, "Tong'asia-esŏŭi Nangnang, Kwaje-wa pangbŏp-e tae-han yŏn'gu" [Nangnang in East Asia, A Study on Tasks and Methods], Han'guk Kodaesa yŏn'gu, June 2005, 13. 
ed on elements of homogeneity, coherency, and continuity. On the contrary, it has proven to be one of the most fragmentary and discontinuous chapters in the peninsula's history, too difficult even for the ancient historians themselves to have left us a clear account of it. On the basis of historical events, Komai delineated a five-period division of the history of Lelang, ${ }^{11}$ from its establishment until its collapse; however, considering the turmoil the continent experienced from the first to fourth century $\mathrm{BC}$, it is likely that Lelang's history witnessed even more ruptures and changes. Moreover, even if we are certain that the Central Plain cast its influence on this territory, it is hard to define the degree to which this territory was subject to the fickle political climate of the rest of the continent. It is at once one of the most crucial, yet most delicate chapters in all of premodern Korean history, an important key to understanding its early development. Nevertheless, it has generally been neglected in traditional history books (Samguk Sagi and Samguk Yusa, for example), and in most recent history textbooks.

From the point of view of ancient local historians, Nangnang has been described as a constant menace. In the "Silla Pongi" of the Samguk Sagi alone, we find six passages referring to hostilities that took place from the time of Pak Hyŏkkŏse to the era of Yuri Isagŭm. The following is the first one recounted in the pages of the book:

"In the third year of Pak Hyŏkkŏse, Nangnang led its army to Silla and tried to attack it." 12

From the first volume of the Samguk Sagi, Nangnang people's behavior is described as “no different from that of thieves" (無異於盜). We also discover in the Samguk Sagi some episodes of military conflict with

11 Komai: 1965, 24-28, in Hyung Il Pai, Heritage Management in Korea and Japan: The Politics of Antiquity and Identity (Washington: University of Washington Press, 2013), 154.

12 Samguk Sagi v. 1, Pak Yŏkkŏse, y. 30. 
Paekche from the time of King Onjo onwards, although there is some doubt as to the reliability of the proposed dating and, more generally, the contents themselves. ${ }^{13}$ Thus, though extremely relevant for researching the origins and the identity of Nangnang, some passages of the Samguk Sagi and Samguk Yusa appear to be contradictory and incoherent, and thus not fully credible.

"According to these sources, Nangnang may be identified with P'yŏngyang-sŏng. But other sources maintain that Nangnang was the land of Malgal at the foot of Mt. Chungdu, and the Salsu is now the Taedong river. It is hard to tell who is right." 14

In this passage, Iryŏn sincerely confesses the limits of his knowledge with regard to Nangnang, as there are many theories to its location, to the point that he himself doesn't know which one is correct. In a further passage, Iryŏn seems to complain about the chaotic state of the information on Nangnang he has gathered.

"King Onjo of Paekche said that Nangnang is in the east and Malgal is in the north. This would certainly make Nangnang a ter-

13 An-sik Mun, "Samguk sagi ch'ogi kirog-e poinŭn Nangnang-ŭi silch'e-e taehayŏ" [On the Real Existence of Nangnang on the Basis of the First Accounts in the Samguk Sagi], Han'guk chŏnt'ong munhwa yŏn'gu, 2008, 198. As Kang notes ("The Real Existence," 136-7), it is likely that some of the first passages of the Silla and Paekche pongi of the Samguk Sagi referring to Nangnang may be somehow incorrect, as they treat Nangnang as a neighbor of Silla and Paekche, while in fact its territory was significantly far from the southern part of Korea. Possibly, he states, it could be a fabrication by later scholars, who probably replaced Chinhan with Nangnang in the records (ibid., 140).

14 據上諸文, 樂浪郎平壤城, 宜矣. 或云樂浪, 中頭山下靺鞨之界, 薩水今大同江也, 未詳勍是. Samguk Yusa, Wonder 1, Nangnangguk. The translations of the passages from the Samguk Yusa in this article are adaptations from the English version of $\mathrm{Ha}$ Tae-Hung and Grafton K. Mintz (Yonsei Press, 1972). 
ritory under the rule of the commandery of Nangnang at the time of the Han Empire. But the people of Silla called their own country Nangnang and even now call a noblewoman 'a lady of Nangnang.' This is shown by the fact that King T'aejo called his daughter, whom he gave in marriage to the surrendered king of Silla, the princess of Nangnang." 15

The Samguk Sagi has also been marred with various inconsistencies as well as probable mistakes, such as we find in the following passage:

"In the east, there is [the territory of] Nangnang, and in the north, [that of] Mohe [Malgal]."16

As already reported in a note on Yi Pyŏng-dos's translation of the Samguk Sagi, there is an evident contradiction in the text, as Nangnang should be in the north, and Malgal in the east. At any rate, these examples show that there was already an active debate about Nangnang among scholars of the Koryŏ period, and even by then, many doubts concerning Nangnang were far from being solved. In recent times, research in this field has failed to produce an exhaustive reconstruction of this phase. By way of example, in a 593-page book titled Ancient History of Korea (Han'guk kodaesa), written by Sin Hyŏng-sik in 1999, there is neither a chapter nor even a single section dedicated specifically to the history of Nangnang; moreover, in the fourth edition of the Outline of Korean History (Han'guksa t'ongnon), by Pyŏn T'aes-ŏp, only three pages deal with the Han commanderies. Nonetheless, it seems that interest in this period has gradually resurfaced since the 2000s. In 2000, Pai Hyung Il published a detailed work on Nangnang "as a case study in cultural contact and cul-

15 又百濟溫祚之言, 曰「東有樂浪, 北有靺鞨」, 則殆古漢時樂浪郡之屬縣之地也. 新羅人亦以稱樂浪, 故今本朝亦因之而稱樂浪郡夫人, 又太祖降女於金傅, 亦曰 樂浪公主. Samguk Yusa, Wonder 1, Nangnang.

16 國家東有樂浪北有靺鞨. Samguk Sagi, v. 23, Onjo, y. 13. 
tural change." Soon after, in 2006, Research on Nangnang, a monograph written by O Yŏng-ch'an, finally restored scholarly attention to this period of history, which had partly fallen into oblivion. Further, in the book Han'guk kokohak kangŭi (Lessons on Korean Archaeology), compiled by the Han'guk Kokohak'oe (Association for Korean Archaeology), an entire chapter, entitled "The Northern Territory," is dedicated to Nangnang archaeology. So far, the most detailed and complete English-language work on Nangnang is the 2013 book The Han Commanderies in Early Korean History, edited by M. E. Byington. Interestingly, the fact that it forms a volume of the Early Korean Project series seems to reinstate Nangnang as part of the history of the peninsula, and avoids estranging it from Korea's past, as previous books have done.

From the very first studies - which date back to the late Chosŏn period and the first archaeological surveys by Sekino Tadashi in 1909-until modern times, ${ }^{17}$ much of the relevant academic literature has focused on the localization of the "Four Commanderies"18 — probably due to the reluctance to acknowledge the presence of foreign rule in Korean territory-or, alternatively, on the identity of the people buried in excavated tombs. ${ }^{19}$ The acknowledgment of a foreign colony in Korean territory

17 Research on the "Han commanderies" dates back to the late Chosŏn period, when such scholars as Han Paek-kyŏm, Yi Ik, Yun Tong-gyu, An Chŏng-bok, Sin Kyŏng-jun, and Chŏng Yag-yong tried to identify the correct locations of the “commanderies." Sŏng-hyŏn Pak, "Hansŏ chiriji Nangnang-gun 3su-ŭi pijŏng-e taehan kŏmt'o" [A Review of Locating Three Rivers of Lelang Commandery in the Book of Han Treatise on Geography], Han'guk kodaesa yŏn'gu 79 (Sept. 2015): 14-39. For a complete reconstruction of archaeological surveys during the colonization period, see In-seung Jung, "Ilje kangjŏmgi-ŭi Nangnang kokohak" [Nakrang Archeology during Japanese Colonial Rule], Han'guk sanggosa hakpo 71 (2011): 149-170.

18 Ho-jŏng Song, "Hangunhyŏn chibae-ŭi yŏksa-jŏk sŏnggyŏk" [Historical Character of the Rule of Han Commanderies], Yǒksa-wa hyŏnsil 78 (2010).

19 Song, "Historical Character," 37. By denying the existence of Han Nangnang, North Korean archaeologists and Yun Nae-hyŏn attempted not only to eradicate undesirable "foreign" (Chinese) influence on Korea's ancient past, but also to dis- 
was a significant hindrance to the legitimacy of the historical narrative, a continuous, linear, and monoethnic historical development rooted in the Tan'gun myth that was strongly asserted in those years. But these studies, from the point of view of the Japanese rulers, served to demonstrate Korean culture's high level of dependence on the Chinese. ${ }^{20}$ In addition to the obvious sensitivity of the subject, one insurmountable obstacle has been the paucity of archaeological data produced by North Korean academics, both for lack of funding and because the misuse of this kind of research could lead to a radically altered perspective on this chapter of the Korean history than what is traditionally maintained, based on a nationalistic theory of "land pureness" (yŏngt'o sun'gyŏljui) ${ }^{21}$ whose very center was P'yŏngyang. Historiographical sources, too, fail to transmit a detailed account of Nangnang's past and compel us to rely on a few passages, reported in nonobjective written records, that have only accidentally survived under exceptional circumstances. The most difficult aspect of this reconstruction is that all existing sources have been written from the point of view of the "rulers"-i.e., of the "winners" - and are reported mainly in the official dynastic histories. Moreover, the archaeological data has been recovered from the tombs of the elite, thus there is no voice allowed to Indigenous people nor to local ones, which further distorts our reconstruction of local society and identity. Consequently, we completely lack an alternative narrative by which to understand this long phase of Korean

credit Japanese archaeological contributions. (Pai, Constructing, 129). In North Korea, Ri Chi-rin proposed the theory of the shift of Ancient Choson to the Liaodong peninsula after the aggression of a Yan General Qin Kai (Pak, "Three Rivers," 31).

20 Hyung Il Pai, Heritage Management in Korea and Japan: The Politics of Antiquity and Identity (Washington: University of Washington Press, 2013), 136.

21 See, for example, In-Sung Cho, "Chosŏn inmin yŏksa kangjwa(1950)-wa yŏksa kyoyuk-Nangnanggun-ŭi wich'i pijŏng-ŭl chungsim-ŭl” [Korean People's History Lecture (1950) in North Korean and History Education-Focused on the Discussion of the Location of Lelang Commandery], Han'guk sahakpo 83 (May 2021): 7-8. 
history from the point of view of the local people - likely the majorityand our reconstruction is limited to the standard perspectives. These "local people" were also a complex ethnic amalgam, having settled over centuries of immigration, struggle, and alliance formation. A reference to the waves of migration directed at the Korean peninsula is found in a passage on King Uija in volume 28 of the Samguk Sagi:

"After the turbulences of the Qin [period], many Chinese people left the Han [territory], fleeing to the Haedong territories." 秦亂漢離之時中國人多瓮海東.

Further archaeological data can hopefully help provide more information on other aspects of the culture and society of this territory in the future, but most of the excavations will still come from the necropolis, which ipso facto means a near-total lack of data from sites inhabited by living people. The number of tombs excavated is also very limited if we consider that only three thousand tombs in the P'yŏngyang area and only a hundred others around the earthen walls of Unsŏng-ni have been discovered until now. They are especially few in comparison to Koguryŏ's tombs, found in the Tonggou, Ji'an area (around 10,782 in number), and also in comparison to the population of Nangnang, which reached a peak of about 400 thousand inhabitants; if we assume an average life expectancy of fifty years-probably a little optimistic for ancient and preantibiotic times - the overall number of people who lived in Nangnang over those four centuries could have been more than three million. Thus, we may assume that the number of remains is astonishingly disproportionate to the actual population of Nangnang. Moreover, these relics belonged only to the material culture of a specific stratum of the local elite; this makes it almost impossible to understand and reconstruct the life circumstances and identity of the Indigenous people. Though we are well aware of these limitations, in this article, we attempt an analysis of Nangnang, trying to discover some elements that may demonstrate-even narrowly or incompletely - some expressions of cultural resistance from the 
local people of the frontier settlement, so that we may be better aware of the traditional, and distorted, notions of this part of Korean history.

\section{Inadequacy of the expression "four Han commanderies"}

At the beginning of the twentieth century, Korean scholars began to seriously question the reliability of those Book of Han passages related to the foundation of "commanderies" in the old territories of Chosŏnabove all, those referring to Nangnang and Hyŏnt'o — to the point that Sin Ch'ae-ho considered them "a false interpolation by scholars of later periods." ${ }^{22}$ However, the seals discovered in the area of P'yŏngyang and the Stele of Chŏmjehyŏn秥蟬縣 (c. Nianti district) — the oldest inscription found in Korea, discovered by Sekino Tadashi in Yonggang-gun in $1913^{23}$ and named after one of the twenty-five districts of Nangnanghave proved the historical existence of a district named "Nangnang-gun." However, the expression "the four [Han] commanderies" that we often encounter in articles and books does not stem from any archaeological relic but appears for the first time in the Records of the Grand Historian, where it is reported that Emperor Wu installed them after a long military campaign against Wiman. The expression "four commanderies" also appears in the Samguk Sagi. ${ }^{24}$ For just a short period, in fact, there did exist four distinct commanderies - those of Nangnang, Imdun (c. Lintun), Chinbŏn (c. Zhenfan), and Hyŏndo (c. Xuantu). However, some of the four were dismissed shortly after their creation; several other "Han commanderies" also existed in parallel, in Liaoning province or other regions

22 Pak, "Three Rivers," 9.

23 Pai, Heritage Management, 126.

24 “Koguryo was originally the four commanderies.” 高句麗本四郡 Samguk Sagi, v. 20, King Yŏng-nyu, y. 24. But a few years later (v. 22, King Pojang, y. 22), it is reported that "Hyŏndo and Nangnang were originally the territory of Chosŏn" (玄莬樂浪本朝鮮之地), which is contradictory. 
of Asia, as did a further one, that of Taebang [c. Daifang], established in AD 204. Moreover, the Samguk Yusa reports the existence of two distinct Taebang commanderies, the northern and southern one. ${ }^{25}$ So the number "four" is not accurate. Furthermore, it is not appropriate to call them "Han" commanderies because, though they were established under Emperor $\mathrm{Wu}$ of Han, they fell under the control of several different rulers. In the specific case of Nangnang, it was under the control of five empires: Westen Han (from 109 BC to AD 8), Xin (8 to 23), Eastern Han (25 to 220), Wei (220 to 265), and Western Jin (265 to 316). Moreover, it appears that Nangnang reaffirmed its own autonomy at a certain point, to the extent that Emperor Gwangwu (r. 25-57 AD) had to send his soldiers to subjugate those territories in $\mathrm{AD} 45 .{ }^{26}$ The area's cyclical enjoyment/restoration of a degree of autonomy is also attested by a passage in the Samguk Yusa, where it is reported:

"[Nangnang and North Taebang] are the names of two counties established under the Western Han; later, North Taebang impudently assumed the status of a country, but then surrendered." 27

Further, when the Suowen Jiezi, compiled in the $121 \mathrm{AD}$, refers to Nangnang, it sometimes calls it "county" (kunhyŏn, 郡縣), other times “vassal reign” (出樂浪藩國). ${ }^{28}$ This expression can be found only in passages related to the territory originally belonging to Ancient Chosŏn, and

25 Samguk Yusa, Wonder 1, Taebang.

26 "In autumn of the ninth month of the seventeenth year, Emperor Guangwu of Han sent his soldiers across the sea to attack Nangnang and obtain its territory, making it his county; thus the territory south of Salsu became part of Han.”二十七年 秋九月漢光武帝遣兵渡海伐樂浪取其地爲郡縣薩水已南屬漢. Samguk Sagi, v. 14, Koguryŏ pongi, Taemusin, y. 27.

27 前漢所置二郡名, 其後僭稱國今来降. Samguk Yusa, Wonder 1, Taebang.

28 Nam-jung Kim, "Sŏlmun Haeja-ŭi Ko Chosŏn-Nangnang kirok-kwa chŏn'gŏ" [The Records of Old Chosŏn and Lelang in Shuowenjiezi and Their Authority], Sŏnsa-wa Kodae 51 (March 2017): 7-8. 
again it seems to show a degree of independence, at least in the collective imagination of some Han intellectuals. Further, it is interesting to observe that in the Paekche Pongi of the Samguk Sagi, we find references to invasions by both Nangnang (for example, year 18 of Onjo, year 13 of Koi) and the Han (for example, year 13 of Ch'aekkye), ${ }^{29}$ thus we have the perception that Kim Pu-sik considered these (Nangnang and Han) to be two autonomous entities.

Taebang was not even established by the Han dynasty, but only much later, by Gongsun Kang, a warlord in Liaodong. ${ }^{30}$ Moreover, due to rebellions and turmoil in China, rulers must have periodically lost their influence over these frontier territories, and the interruption of transportation links with inland China probably often led to a shortage or even a complete lack of Han personnel and of military and political control over Nangnang. ${ }^{31}$ The relation of these commanderies to the Han dynasty, though recognized by the Samguk Yusa (Wonder 1, Old Chosŏn), is nonetheless expressed in a very imprecise passage, where it is reported:

"The Han dynasty divided Chosŏn into three counties: Hyŏndo, Nangnang, and (Northern) Taebang." The Tongdian gives the same account. However, the Book of Han tells of four countries (Chinbŏn, Imdun, Hyŏnt'o, Nangnang) with names different from those in the other sources, for some unknown reason."

漢分置三郡, 謂玄菟. 樂浪. 帶方北帶方. 通典亦同此說. 漢書則眞 臨樂玄四郡 今云三郡 名又不同, 何耶.

Again, in a subsequent passage on the seventy-two states, Iryŏn refers to the Book of the Later Han, and cites four kun (四郡) and two pu (二府):

29 十三年秋九月漢與貌人來侵. Samguk Sagi, v. 24, Ch'aekkye, y. 13.

30 The southern Taebang was established during the Cao Wei dynasty. 曹魏時始置南 帶方郡. Samguk Yusa, Wonder 1, Taebang.

31 Yŏng-ch'an O, Nangnanggun yŏn'gu [Study on Nangnanggun] (Seoul: Sagyejŏl, 2006), 114. 
"The Book of the Later Han says, 'Western Han first divided the land of old Chosŏn into four counties and then installed two prefectures."”

後漢書云西漢以朝鮮舊地, 初置爲四郡, 後置二府.

This confirms that already by the time of the Samguk Yusa's compilation, there was a degree of uncertainty as to the origins, evolution, and identity of these "Han commanderies." Moreover, as seen in the previous passage, these four kun (郡) were later converted or integrated into two $p u$ (府). This suggests that the status of Nangnang changed significantly over time. In any case, the word "commandery" is problematic, as it already implies the complete military character of this institution. The term $p u$ or “external administrations" (外府) ${ }^{32}$ may to some extent be linked to a sort of autonomous and external administration (都督府) with jurisdiction over a wider territory. However, the governors (or magistrates) who administered the territory, while surely a military power, ${ }^{33}$ were not necessarily soldiers or generals, but more probably high-ranking civil functionaries or even local chiefs. If we look at the images of the governors (or magistrates) depicted some decades after the fall of Nangnang in North Korean

32 The term "prefecture" also appears in a previous passage, which reports: "In the Book of Han, it is written, 'In the fifth year of Han Emperor Zhao (82 BC), in the year of Kihae, two external prefectures were installed, P'yŏngna and Hyŏngdo, as Command of P'yŏngju, while the two counties of Imdun and Nangnang installed the Eastern Command.' But the Chaoxianzhuan states, 'The country was divided into four counties — Chinbŏn, Hyŏndo, Imdun, and Nangnang." The "P'yŏngna" mentioned in the Book of Han is probably Chinbŏn. 昭帝始元五年己亥, 置二 外府, 謂朝鮮舊地平那及玄菟郡等, 爲平州都督府, 臨屯·樂浪等兩郡之地, 置東 部都尉府. 私曰, 朝鮮傳則眞番·玄菟·臨屯·樂浪等四, 今有平那無眞番, 盖一地 二名也. Samguk Yusa, Wonder 1.

33 In the Old Rites of the Han by Ying Shao, it is reported that "the governors of frontier commanderies patrol the fortifications and beacons with the cavalry and guard against foreign enemies." Quoted in Dae-Jae Park, "A New Approach to the Household Register of Lelang Commandery," International Journal of Korean History 22, no. 2 (August 2017): 21. 
mural paintings, specifically those from Anak tomb no. 3 (AD 357) and the Tŏkhŭng-ni tomb (AD 408), we can see that they don't wear armor, preferring to wear civil garments instead of military ones. In addition, archaeological surveys show that the amount of weapons and military equipment progressively decreases in the tombs, especially after Wang Diao's revolt. ${ }^{34}$ Naturally, the use of military power was essential for the control and maintenance of these frontier and lucrative lands. The prevalence of weapons as burial goods in several tombs undoubtedly suggests that, to some extent, the status of warrior was a particularly relevant social factor at this time, but the same assumption is also true for previous and later periods and is generally applicable to ancient periods on the whole. Moreover, this territory was a frontier and so inevitably required a degree of militarization and defense systems more sophisticated than other inland territories.

Based on the meaning of its components, the Chinese character jun 郡 on its own refers to "a village under a lord," and its translation as "commandery" seems inappropriate or forced, as we find no explicit reference to a uniquely military administration. A more suitable translation would probably be the more neutral "frontier settlement," as the term jun may be a contraction of bianjun (邊郡), or “frontier settlement.” We don't know much about the degree of autonomy a "frontier settlement" would have had at that time. The concept of "colonial installation" or "colony" may fit somewhat better than that of "commandery," though the word "colonial" itself is problematic as it contains many more political implications and also seems to imply a sense of complete and irreversible control. Though we normally refer to ancient Phoenician, Greek, and Roman communities abroad as "colonies" without reservations, in the case of Korea, the Japanese "colonial" experience and its own uncomfortable geopolitical position in Northeast Asia has made some scholars particular-

34 M. E. Byington (ed.), The Han Commanderies in Early Korean History (Harvard: Harvard University, 2013), 92. 
ly sensitive to the potential use of this word. ${ }^{35}$ In the ancient world, a "colony" (from the Latin verb colere, "to cultivate") originally referred to a group of people or community who settled in a distant land to inhabit it, cultivate it, and impose the rules and habits of their motherland, with which they maintained legal and economic ties (e.g., the Greek colonies of Sicily). From the point of view of the empire, veritable "control" of a noncontiguous frontier territory, such as Nangnang, probably appeared precarious and onerous; to some extent, influence over it was more cultural or psychological than strictly military or economical. The empire's influence was generally exerted from a distance (Luoyang, the capital of the Han Empire, was 1,400 km away, or 5,000 li as reported in the Book of the Later Han) and the empire's interference was frequently contested. Wang Diao's rebellion in AD 25 is clear proof of the level of local dissatisfaction with their external management: on this occasion, Wang Diao, a t'oin (土人) — that is, an Indigenous person - killed Liu Xian, the governor of Nangnang, and established his own regime. ${ }^{36}$ Moreover, the number of districts under the jurisdiction of Nangnang shrunk from twentyfive during the Western Han to eighteen during the Eastern Han, probably again responding to local resistance, which made it difficult to keep the administration of these districts under control. At the same time, the population of 406,748 that had been recorded in AD 2 - according to data reported in the Book of Han - had reduced dramatically to 257,050 by AD 140. If this was not caused by a natural disaster or war, the data can only

35 Since 1910, research on Nangnang has often in fact been used to legitimize Japanese colonial rule of Korea. In this regard, see Yi, "Nangnang in East Asia" and Pŏp-jong Cho, "Nangnanggun-ŭi sŏnggyŏk munje" [The Problem of the Identity of the Nangnanggun], Han'guk kodaesa yŏn'gu 12 (2005): 161-189. In the period of Japanese colonization, students were taught that the Commandery of Lelang had controlled the northern part of the peninsula for more than 420 years. As Cho states ("Korean People's History Lecture," 7), it was an attempt to make the Korean people aware of their colonial past to encourage them to "fatalistically" accept Japanese rule.

36 Book of the Later Han, 76, Biographies of Upright Officials. 
show a reduction of the empire's capacity to cast its influence or even collect information from those territories.

Perhaps, even though it is geographically and chronologically distant from the case at hand, we might try to consider the term oppidum, used also to refer to some Roman colonies in French territory. In some cases, this designated the capital of allied people, ${ }^{37}$ but under a different statute. The people of ancient Mediterranean France developed important trading relationships with Etruscan merchants, importing wine in ceramic amphoras, bronze vessels, and fine drinking bottles from them. These colonial encounters intensified after BC 600. At that time, the Indigenous populations of Iron Age Mediterranean France began to concentrate in highly fortified, densely settled sites, often situated on commanding hills or at strategic points. Archaeologists generally refer to these Iron Age settlements as oppida, of which Lattara, Nages, and Ambrussum are typical examples. ${ }^{38}$ Among the hypothesis the word derives from the archaic Latin ob-pedum, "enclosed space," probably a fortified one. Thus it is a fairly fluctuating category of protohistoric agglomerations, generally defined according to the presence of such an enclosure, ${ }^{39}$ within which the entire economy and political control of the territory was concentrated. In a passage from the Book of Later Han dating back to the reign of Guangwu, Nangnang is, interestingly, called “fortress" (夫餘犯樂浪塞). ${ }^{40}$ In the Records of the Grand Historian, only the siege on the capital Wanggorm is reported, but there is no specific reference to the attack or subjugation of

37 M. Tarpin, “Oppidum secondaire et agglomérations secondairs: continuités et discontinuités entre des structures rubaines et infravicique mal définies," in Sine iniuria in pace vivatur: A construción do Imperio durante os Xulio-Claudios, ed. Ma Dolores Dopico Caínzos and Manuel Villanueva Acuña (2020), 93, n. 48.

38 B. P. Luley, "Cooking, Class, and Colonial Transformations in Roman Mediterranean France," American Journal of Archaeology 118, no. 1 (January 2014): 36.

39 Tarpin, “Oppidum secondaire," 93.

40 Book of Later Han, Emperor Guangwu, fifth year. Puyŏ invaded Nangnang fortress. 
other territories, ${ }^{41}$ this corroborates the hypothesis that first Wanggŏm, then Nangnang was the real political and economic center of the wider territory, as was the case of some European oppida.

Alternatively, if we consider the economic relevance of this strategic installation, we may find some elements of a trade center in which continental communities joined local elites to integrate local commerce into a wider international network. As happened similarly in the archaic Mediterranean, the Greeks created "political communities, mostly independent, with no contiguous territory and no single political center coordinating them, which functioned as a decentralized network." 42

Ultimately, Nangnang was probably the result of the intensification of trade and contact with the Central Plains, but at the same time, it was built on compromises and alliances between external, multiethnic powers and communities and local, native groups. A relatively small number of imperial servants dispatched to such a far territory could hardly control the entire territory military and command a much larger population, imposing taxes and corvée labor on Indigenous people. Moreover, the territory was hardly accessible by land, and even if it was originally and formally under the control of the emperor, direct management of the territory was unrealistic. Several functionaries were sent from neighboring territories, such as Liaodong, but ultimately, it was necessary to recognize the authority of local chiefs, to delegate to them, and to cooperate with them in maintaining public security. ${ }^{43}$ As already underlined by Kim, ${ }^{44}$ the Han generals who led the attack against Wiman Chosonn were punished after the war, and paradoxically, only subjects from the defeated Wiman Chosŏn were rewarded at the end of the hostilities. ${ }^{45}$ We cannot know with certainty

41 Kim, "Wiman Chosŏn-ŭi," 74-5.

42 I. Malkin, A Small Greek World. Networks in the Ancient Mediterranean (Oxford: Oxford University Press, 2012), 3-5.

43 Byington, The Han Commanderies, 267.

44 Kim, "Wiman Chosŏn-ŭi," 78.

45 Sima Qian, Records of the Grand Historian, vol. 115, Chaoxianzhuan, 55. 
how the Indigenous people felt emotionally after the fall of Wiman, and whether they started thinking of belonging to the empire. As Kim asserts, ${ }^{46}$ if it is true that Wiman Chosŏn was not a centralized kingdom, but rather a sort of confederation whose leading power was that of Wiman Chosŏn, it is likely that, after its fall, the Indigenous people may have noted only a formal shift in the leadership of the confederation, while the local order was generally preserved. It was probably an opportunity for some of them to start new lucrative ventures along the new routes of the Han Empire. ${ }^{47}$ Surely. they had to start quickly to adapt to the new standards of administration and new bureaucratic systems. An augmented foreign presence in the area incontrovertibly activated new channels for the transmission of continental trends in the peninsula, and progressively strengthened commercial routes between Northeast Asia and other regions of the empire. It was also likely that local people were officially sent to the Chinese court or to Han cities to learn the law, morals, and habits of the empire, and, once there, they were fascinated by the prestige of the Central Plains civilization.

\section{Increase in the bureaucratization of the Chosŏn territory}

Historical sources generally tend to explain military actions toward subjugated peoples as principally defensive, but a military campaign so risky and far away as that of the Han against Chosŏn was unlikely to have been truly "defensive." 48 Moreover maintaining control of these territories was extremely onerous and difficult, as we can assume from the fol-

46 Kim, "Wiman Chosŏn-ŭi," 75.

47 Dae-Jae Park, "Nangnanggun-gwa Ko Chosŏn yumin" [The Nangnanggun and Immigrants in Ancient Chosŏn], Nangnang kokohak kaeron (Seoul: Chininjin, 2014), 46.

48 "Now the Han army came from far away and is fighting." Samguk Sagi v. 14, King Taemusin, y. 11 (AD 29). 
lowing passage from the Samguk Yusa (Wonder 1, Wiman):

"When the Han arose, finding it difficult to control this remote territory, they restored Liaodong fortress and established the frontier along the P'aesu river."

漢興爲遠難守, 復修遼東故塞, 至浿水爲界 ${ }^{49}$.

It is interesting to note that, even in Roman sources, texts repeatedly report that the Roman emperor decided to launch an offensive "in order to defeat tribes that invaded Roman territory." Isaac argues that this set of actions is described "so frequently and in so similar a fashion"50 that it seems to be the standard explanation for any military venture the emperor decided to undertake; he characterizes Roman expansionary policy as "opportunistic." 51 The territory of Nangnang must have seemed very strategic and lucrative in the Hans' eyes. As we have already seen, from the prehistoric period onward, many people from China had already moved to Northeast Asia, flowing into the Korean peninsula, and even before 108 $\mathrm{BC}$, many waves of immigrants had cyclically arrived in the territory in search of safety or better living conditions. ${ }^{52}$ Nangnang represented a crucial hub in the middle of East Asia, between the Han Empire and East Asia, and held a privileged position that allowed it to control commercial activities down to the Japanese archipelago. Especially after the diffusion of iron weapons and utensils, the need for iron caves made it strategic to maintain commercial routes with southern Korea. The importation of other goods, such as salt and hemp $\mathrm{p}^{53}$ or fishery products, was likely profita-

49 The same passage is also sin the Records of the Grand Historian, Chaoxianzhuan.

50 B. Isaac, The Limits of Empire: The Roman Army in the East (Oxford: Clarendon Press, 1993), 29.

51 P. S. Wells, The Barbarians Speak: How the Conquered People Shaped Roman Europe (Princeton: Princeton University Press, 2001), 75.

52 Yŏng-ch'an O, Nangnanggun yŏn'gu [Study on Nangnanggun] (Seoul: Sagyejŏl, 2006), 22.

53 Ki-baek Yi and Ki-dong Yi, Han'guksa kangjwa (Seoul: Iljogak, 1982), 72-73. 
ble as well. As Yi notes, Nangnang was situated at a latitude near which many of Eurasia's ancient cities were built, in the very middle of a territory that harbored different cultures based on different subsistence economies, such as agriculture, hunting, fishing, pastoralism, and nomadism. ${ }^{54}$ It thus became a crossroads between the routes leading to Northeast Asia, linking the Korea peninsula, the Japanese archipelago, and the Chinese mainland, but was also connected with the northern regions of Siberia.

The conquest and then control of that territory was very demanding, and required a considerable amount of resources, as confirmed by the records of the ruinous campaigns against Wiman reported in the Records of the Grand Historian. Fortunately for the Han Empire, from its foundation to the era of Emperor $\mathrm{Wu}$, the empire enjoyed a period of seventy years free from wars and calamities, during which it saved enough resources to invest in military operations. The Han Empire adopted a policy of expansionism, aimed at conquering more territories, but at the same time, it also had to prepare official internal propaganda to assure its domestic support and not undermine its image. As Brent Shaw has noted, there was an "ideological necessity for a negative image of the barbarians," 55 whom the authors portrayed in stereotypical ways. This helped create the premises of iusta causa that could legitimate aggression against these peoples. First of all, as already seen in the quotation from the Records of the Three Kingdoms, the sources tended to emphasize the binary oppositions of Han and $\mathrm{Hu}$, Han and non-Han, civilized and uncivilized, locals and nonlocals. This rhetorical process itself implicitly placed "nonHan people" in a potentially dangerous group that did not adhere to common rules or principles or who enjoyed fewer rights. In volume 73 of the Han Book, the people of Chosŏn were expressly depicted as a menace to

54 Byington, The Han Commanderies, 165-168.

55 B. D. Shaw, "Rebels and Outsiders," in The Cambridge Ancient History, vol. 11, The Imperial Peace, A.D. 70-192, ed. S. A. Cook, F. E. Adcock, and M. P. Charlesworth (Cambridge: Cambridge University Press, 2000), 382. 
the empire, as the "shoulder of the Xiongnu." that King Ugo attracted exiled people from the Han Empire and didn't allow other neighboring countries to reach the Han court. But the Han were for some reason not fully satisfied with this conquest. ${ }^{57}$

It is difficult to estimate how much such military campaigns could cost, but we could refer to the Roman case for a conjecture: according to Duncan, the cost of the army and salaries for officials alone probably made up over 85 percent of the estimated imperial expenses of the empire. ${ }^{58}$ The Han, replicating their juridical and fiscal standards locally, probably tried to create a system that could allow Nangnang to be economically independent of the empire's aid. This required that a strict and detailed code of rules be enforced on the local people. The "Treatise on Geography" in the Book of Han, volume 28, reports that under Chosŏn, only eight distinct laws existed, which increased exponentially, to more than sixty, after the installation of Nangnang. ${ }^{59}$ We do not know the extent to which the Nangnang law differed from the empire's, ${ }^{60}$ but it at least supplied proof of the maturation of the local administration's standards. Contextually, the presence of seals recovered from archaeological sites also demonstrates an enhanced level of bureaucratization of tax management within the territory. The empire also undertook a systematical ethnographic survey of these territories, trying to form a better idea of the languages, cus-

56 Book of Han, v. 73, Wei Xian Zhuan.

57 Sima Qian, Records of the Grand Historian, vol. 115, Chaoxianzhuan, 55.

58 See Richard Duncan-Jones, Structure and Scale in the Roman Economy (Cambridge: Cambridge University Press, 1990), 33-7. "It has been suggested that military spending was roughly half of total expenditures under Augustus [...], though others calculate that it was more like three-quarters"; E. N. Luttwak, The Grand Strategy of the Roman Empire (Baltimore: Johns Hopkins University Press, 2016), 16.

59 Book of Han, v. 28, Treatise on Geography.

60 Nam-jung Kim, "Sŏlmun Haeja-ŭi Ko Chosŏn-Nangnang kirok-kwa chŏngŏ" [The Records of Old Chosun and Lelang in Shuowen jiezi and Their Authority], Sŏnsa-wa Kodae 51 (March 2017): 21. 
toms, and economy of frontier territories, as shown by the Shuowen jiezi. $^{61}$

In any case, the most credible proof of the hybridization of the local bureaucratic standards was the discovery of a census register dating back to $45 \mathrm{BC}$; called "The [two characters are missing] of the Increase and Decrease in the Number of Households in Lelang Commandery by County in the Fourth Year of Chuyuan" (Nangnang Ch'owŏn sanyŏn hyŏnbyŏl hogu taso, 樂浪初元四年 縣別 戶口多少 $\square \square$ ), it was found at the beginning of the '90s in the wood-frame tomb of Chŏngbaek-tong, no. 364, though it was officially published by North Korean scholars only in $2006 .{ }^{62}$ This represents an important source providing information on the governing system of the Han dynasty in this frontier region. As Park underlines, this discovery has allowed scholars to learn that the central government had a detailed understanding of the number of households in Nangnang, and that such detailed records could only be created within an established administrative system based on official written documents and laws. ${ }^{63}$ The tomb probably belonged to a songni who was in charge of the document's redaction, as we can deduct from the traces of a knife used to delete mistakes from the document, as well as the ring of a belt. ${ }^{64}$ The number of registered people is divided into two categories: pormho (凡戶), which probably refers to the entire population or, as Park claims, denotes the sum of all households and residents in Lelang Commandery (as also

61 Kim, "Sŏlmun Haeja-ŭi Ko Chosŏn," 5-28.

62 Chung'ang munhwajae yŏn'guwŏn, Nangnang kokohak kaeron, 40.

63 See Park, "Household Register," 8-9. It was first published in the book Chosŏn tandaesa (Koguryŏ 1) by Son Yŏngjong in March 2006, then republished in an article that same year. In July 2008, a picture of the document was published and some data corrected. Kwang-ŭi Ko, "Nangnanggun ch'owŏn sanyŏn hogubu chaekŏmt'o" [New Analysis of the Household Register in Nangnang Commandery in the Fourth Year of Chuyuan], Han'guk mokkan hakhoe, July 2011, 16.

64 Yong-gu Yi, 'P'yŏngyang ch'ult'o Nangnanggun ch'owŏn sanyŏn hyŏnbyŏl hogubak" [The Census by County of the Fourth Year of Chuyuan from the Nangnanggun], Han'guk mokkan-gwa munja 3 (2009): 268. 
shown in the household registers of other "commanderies" during the Han dynasty), ${ }^{65}$ and kiho (其戶), which, according to Son Yŏng-jong ${ }^{66}$ — who first introduced the register to the academic world - are the locals, as they represent $86 \%$ of the entire population.

It is generally accepted by the academic community that kiho corresponds to the Indigenous population of ancient Chosón, also called t'oho (土戶). They were most probably people without rights, such as Roman peregrini.$^{67}$ The census also shows that the population was concentrated in the two main districts, Chaoxiang in the north (approximately 55,000 people in 10,000 households) and Taebang in the south (29,941 people in 4,346 households). ${ }^{68}$ There is no doubt that the census was neither infallible, but by premodern standards, it must have been a useful instrument for the government to guarantee the financial basis of this frontier territory. Perhaps the amount of wealth collectible from the people increased over time, as we can deduce from the increased complexity of the tombs over time. A single two-chamber brick tomb required more than ten thousand bricks, based on a calculation made on the walls of Yangdong-ni nos. 3 and 5. ${ }^{69}$ Local elites had to play a special role as mediators between the

65 Park, "Household Register," 14.

66 Yŏngjong Son, "Ryodong chibang Chŏ nhan Kunhyŏndŭr-ǔi wich'i-wa kŭ hu-ŭi pyŏnch'ŏn 1" [The Location of Former Han Counties in Liaodong and Changes Afterwards, 1], Ryǒksa kwahak 199 (2006): 30-33. Even if there are other more cautious opinions, and even if the character 'kon' originally deciphered by Son has been reinterpreted as ' $k i$ ', most scholars agree generally on this interpretation (Park, Dae-Jae, "Nangnanggun-gwa Ko Chosŏn yumin" [The Nangnanggun and Immigrants in Ancient Chosŏn]. Nangnang kokohak kaeron. Seoul: Chininjin, 2014, 43.

67 It is interesting to note that in the first and second centuries, the majority of the Roman Empire's population, about 80 to $90 \%$, was made up of peregrini. In ancient Rome, a peregrinus was a free person who was subject to Roman rule without having Roman citizenship, and therefore lacked many rights reserved for Roman and Latin cives.

68 Byington, The Han Commanderies, 30.

69 Chung'ang munhwajae yŏn'guwŏn, Nangnang kokohak kaeron, 67. 
new continental communities, and probably the locals as well, and to assure that taxation rules would also be respected in rural areas. ${ }^{70}$

\section{Hybridization of Nangnang culture}

At the time of the fall of Wiman, there existed no standardized Han culture, but rather an assortment of different local traditions, constantly changing over the centuries. Nangnang culture itself was extremely complex, inasmuch as it was a frontier where identities were in a state of continuous change and competition with each other. As Di Cosmo asserts, "The imperial frontier system established by the Han was a living administrative organism that changed over time in response to both local and central pressures, and the experimentation carried out by the Han along the frontiers impinged upon later theories, debates, policies, and practices." ${ }^{71}$ Furthermore, neither its ruling class nor its population was uniform in its ethnic composition over time; each was an amalgamation of multiple ethnic and regional groups. We might apply to the Han Empire what Wells asserts of Roman tradition: "Past approaches have tended to overemphasize standardization in the Roman provinces and to neglect the important evidence of local and even individual variation."72 Though Han culture influenced the local one and probably fascinated the local elite, we should avoid the word "Hanization" (Lelang-ization"3 or even more inappropriately Sinization) as this kind of expression is "based on a now outmoded concept of acculturation, whereby the representatives of the larger, more complex culture brought the obvious benefits of their lifestyle to

70 Wells, The Barbarians Speak, 116.

71 N. Di Cosmo, "Han Frontiers: Toward an Integrated View," Journal of the American Oriental Society 129, n. 2 (2009): 200.

72 Wells, The Barbarians Speak, 189.

73 Rakuroga 樂浪化, in Mikami Tsugio, Mansen genshi funbo no kenkyū (Tokyo: Yoshikawa kōbunkan, 1961), 72 (quoted in Pai, Constructing, 72). 
more primitive peoples, who eagerly adopted it."74 Changes in Nangnang were very complex and cannot be reduced to any specific formula.

Such changes started even before the Wudi era, but they were the result of the deliberate strategy of local elites. A tendency to draw cultural elements from abroad was not typical of this period or previous ones; we find a very telling late passage on King Hŭngdŏk of Silla in the Samguk Yusa:

"But the customs have deteriorated and people quarrel as they vie for luxury and extravagance, and they only treat precious objects from abroad with respect, and consider the local ones vulgar."

只向異物之珍貴却嫌土産之鄙野. ${ }^{75}$

The archaeological data shows a complex pattern in which Indigenous traditions were combined with elements introduced by Han culture; however, the phenomenon of hybridization probably started well before the installation of Nangnang, and also indirectly involved territories not under the control of the empire, such as southern Korea and Japan. ${ }^{76}$ Moreover, its influence persisted even after the fall of Nangnang and Taebang - as we see, for example, from the fact that brick-chambered tombs did not fall out of fashion after the fall of these installations, but continued to be built in the territory until at least AD $407 .{ }^{77}$ Also, as Pai underlines, "The geographical distribution exhibits a decrease in Han materials and influence with increasing distance from the center at P'yŏngyang." "78

We should be aware that by labeling this phenomenon as "Hanization,"

74 D. J. Mattingly, Imperialism, Power, and Identity (Princeton: Princeton University Press, 2011), 126.

75 Samguk Sagi, book 33, 200.

76 O, Nangnanggun yŏn'gu, 91.

77 Ibid., 229.

78 Pai, Heritage Management, 174. 
we risk creating the artificial impression of continuity and homogeneity in the culture of Nangnang and completely annihilating the role of the local people and culture in the construction of its identities. We should try to ascertain how the local people and ruled subjects mutually participated in the construction of Nangnang society, or better, the "societies" that emerged in this frontier territory. As the archaeology of Roman colonies demonstrates, "The people inhabiting the frontier provinces became increasingly heterogeneous as they responded to the changes resulting from the Roman presence"79: results from archaeological surveys also confirm this trend for the area under the rule of Nangnang. For instance, the type of buried objects changed significantly over time, showing the progressive contamination of local tastes under the influence of new, continental ones; nevertheless, local artifacts were not banned from burial practice. In the Nangnang tombs, we have found bronze vessels, jades, and expensive lacquerware $^{80}$ - quite unusual in the field of Korean archaeology-yet these were often buried alongside such locally manufactured objects as bronze daggers.

Especially after the appearance of the log-frame tomb type, there was a significant increase in the number of objects from the Central Plains, which came to predominate in the tombs. This undoubtedly reflects the growing prestige of Chinese culture to people living in this territory, and it is unlikely that the cultural level of Nangnang was so different from that of Luoyang; Song asserts that such wealth was not frequent, even in tombs excavated in China. ${ }^{81}$ Some lacquerware found in the tombs of Nangnang was of the same type as that used by the imperial house: ${ }^{82}$ these objects were extremely highly valued, to the extent that they could

79 Wells, The Barbarians Speak, 187.

80 Tombs excavated in North Korea likely belong primarily to local elite, as corpses of the foreign functionaries were not interred locally, judging from the practice of sending their bodies back to the empire for burial. See for example, Cho, "The Problem of the Identity," 164.

81 Byington, The Han Commanderies, 159.

82 Song, "Historical Character," 28. 
cost 1,200 each, as reported in the "Biographies of Moneymakers" in the Records of the Grand Historian. Further, the presence of molds to make coins and bronze objects ${ }^{83}$ proves that Nangnang had an active and independent economy and was a site of advanced production at that time. Although a large quantity of lacquerware has been discovered in China, it is difficult to find precious items comparable to those found in Nangnang; however, this is also probably due to the fact that wood is easily perishable, and many precious objects buried under the earth have since completely decomposed. ${ }^{84}$ As reported in the Lunheng, vol. 19, Huiguopian (恢國篇), Lelang was recognized as a highly civilized place where people wore leather crowns (皮弁), a place where in the Zhou required two interpreters, and now they could chant the Shijing and the Shujing. ${ }^{85}$ As Ko notices, even the calligraphic style of the census register follows continental trends. In the passage in clerical script, some characters from the seal style were also used, and this same style can broadly be seen in the second part of the Eastern Han period. ${ }^{86}$

Perhaps Han portable material culture - just like its counterpart in temperate Europe - was used by Indigenous peoples, especially elites, who wanted to display their familiarity with and access to the latest cosmopolitan trends in architecture, pottery, glassware, and personal ornamentation. ${ }^{87}$ This was also an instrument for local elites to show off their power and international reputation, and to allow them to have their power recognized internally.

In fact, just as in Rome, once the initial trauma of invasion was overcome, ${ }^{88}$ the society's change of circumstances was probably viewed as a

83 Chung'ang munhwajae yŏn'guwŏn. Nangnang kokohak kaeron, 132.

84 Kyŏng-gu Kang, "Nangnang ch'ilgi-ŭi munjejŏm”" [Some Questions about Nangnang Wooden Lacquerware], Han'guk Sanggosa hakpo 14 (1993): 409.

85 Chong Wang, Lunheng II, vol. 19, trans. Alfred Forke (New York: Paragon Book Gallery, 1962).

86 Ko, "New Analysis," 21-22.

87 Mattingly, Imperialism, 269.

88 For a vivid description of trauma following an imperial invasion, see for example 
positive development by some of the population, as it introduced a higher level of technology to the territory while also allowing native talent access to new opportunities within the empire. If we once again consider the case of colonial Rome, this process of opening up would mostly have involved the elite class, who were the agents most active in first promoting the adoption of Chinese as the official language, and then new styles of dress, architecture, and behavior, "while people lower down the social spectrum experienced a more diluted version of [influence], through emulation of their social betters." ${ }^{89}$ Indigenous people continued to use everyday objects made mostly of perishable materials like wood and clay, while those used by their elite counterparts - made of bronze, jade, and lacquer-were much more durable.

Furthermore, we may note that, in spite of the installation of Nangnang in $108 \mathrm{BC}$ and the sudden political changes in the area, the production and use of the local slender bronze daggers - produced in this territory from at least $300 \mathrm{BC}$-was not interrupted, as we see from the woodframed tomb of Chŏngbaek-dong no. 1, where a local chief was buried together with his locally made weapons. Slender bronze daggers were unique to the Korean peninsula and can clearly be distinguished from the Liaoning style. ${ }^{90}$ Even in the tomb of Changbaek-tong no. 364, a slender dagger has been discovered, together with the census register and volumes 11 to 12 of the Analects. ${ }^{91}$ This eclecticism of funerary goods shows the high level of hybridity reached by local elites.

This further proves that the foundations of local economy and power had not yet completely eroded, a hypothesis that is also corroborated by the discovery of other items, such as Korean-style sheaths, bronze spear-

Shaw, "Rebels and Outsiders," 377-8.

89 M. Millett, The Romanization of Britain (Cambridge: Cambridge University Press, 1990), 206.

90 Byington, The Han Commanderies, 110.

91 Yong-gu Yun, "Nangnang-gun hogubu-ŭi palgyŏn-100nyŏn Nangnang kokohakŭi ch'oedae suhwak," Naeil yŏnŭn yŏksa 63 (June 2016): 152-4. 
heads, and harness equipment. ${ }^{92}$ In addition, some silver and golden fibulae and objects manufactured with inlaying techniques ${ }^{93}$ from northern cultures have been discovered in tombs dated to the first century $\mathrm{AD}$, such as that of Sŏg'am-ni, no. 219. Thus, even ties with Xiongnu or the northern populations were not completely severed after the installation of Nangnang. All these relics may simply be interpreted as a natural continuation of local traditions, as partial cultural autonomy, or as a show of tolerance for local habits. However, they cannot be seen merely as the passive heritage of the past, but more as an active manifestation of cultural resistance in the face of external influence. These objects mirrored the identity of part of the local society and embodied their values either in part or in whole.

Another feature to underline is that, based on the analysis of artifacts discovered in the Nangnang tombs, the reception of Chinese culture from the Central Plain was much more intense during phases of instability, such as the end of the Eastern Han or throughout the Xin dynasty, rather than when the power of the Han Empire was at its height. This again suggests that the transmission of some aspects of Han culture was not a massive, unilateral imposition from the Han Empire, but rather a deliberate and gradual adoption on the part of local elites probably fascinated by Han culture, which had been introduced by Han immigrants and was immediately appreciated in other cities of the empire. As we have seen, Nangnang was culturally far from homogenous. Along with the buried objects, the structure of the tombs itself varied greatly, and these inconsistencies can be understood as an indicator of radical change in local society-more than just a simple maturation of architectural techniqueor as evidence of change and disparity in the succession of power. The tomb system evolved from a wood-framed type (목곽묘, first century BC)

92 O, Nangnanggun yŏn'gu, 158.

93 Kyŏng-mi Chu, "Nangnang kobun ch'ult'o kŭmgongp'um" [Metal Objects Excavated from Nangnang Tombs], in Nangnang kokohak kaeron, ed. Chung'ang munhwajae yŏn'guwŏn (Seoul: Chininjin, 2014], 229. 
to a log-framed one (귀틀묘, first and second century AD), and then to a brick-chambered type (third and fourth century $\mathrm{AD}$, 전실묘) ${ }^{94}$ Despite this considerable diversity, the tendency to label Nangnang as a unique outcome of Han civilization risks transmitting a distorted perception of the development of local society and culture. Just as there was no homogeneous Han culture, there was also no single, standard Nangnang one. Therefore, we should concentrate more closely on the analysis of these fractures and gaps in Nangnang's history to better reconstruct the evolution of its past. We could take inspiration from the approach of Edward Said and his concept of discrepant experience, which proposed to explore different narratives of colonial pasts, not just those based on the historical accounts of the victors. In fact, such accounts tend to vastly oversimplify some crucial problems, and to reduce them to binary oppositions between ruler and ruled (Han and natives, in this case), as we see in the following passage from the Records of the Three Kingdoms:

"[The Emperor Wu of Han attacked Chosŏn and defeated it and installed in that territory four commanderies]. Since then, the distinction between $\mathrm{Hu}$ and $\mathrm{Han}$ has progressively increased. (漢武帝伐滅朝鮮, 分其地為四郡。自是之後, 胡漢稍別.)”95

The term "Hu" refers to local people, as we also find explicitly in the expression "the Hu Kingdom of Chosŏn," reported in a passage from the Book of Han's "Treatise on Geography," where it refers to local people before the installation of Chinbŏn. ${ }^{96}$ We should ideally avoid such dichotomies and instead explore the full range of divergences between these two communities, Chinese and "barbarians"; however, the limits of the archaeological finds make this work especially difficult. The community of the Han people itself was very complex and variegated: even before the

94 O, Nangnanggun yŏn'gu, 74-75.

95 Sanguozhi, v. 30, Weishu, Dongyizhuan, Ye.

96 See Park, "The Nangnanggun and Immigrants," 45. 
installation of Nangnang, there existed a large group of mainland immigrants, probably people exiled from the communities attacked by the Qin and the Han. The presence of exiled people from previous times was so prominent that the native people of Nangnang called themselves "Qin." At a certain point, it is likely that a consistent community from Nangnang moved to Silla, as a passage in the Samguk Yusa reports that the Silla people called themselves "Nangnang people."

"The people of Silla called their own country 'Nangnang,' and even to this day call a noble lady a 'lady of Nangnang.",98

This exodus from continent to the peninsula seems to have intensified with Wiman's rise to power, who himself was an exile from the state of Yan. ${ }^{99}$ The Records of the Grand Historian's "Account of Chosŏn” states that the number of Han Chinese taking refuge in Old Chosŏn had increased considerably and that these people were illegally accepted. The migration of many Han people risked tarnishing the emperor's image, which is why the situation provoked a reaction from the Han court. Even among these immigrants, there were many heterogeneities, for example in their class affiliations: among them we find high-ranking officials, such as governors (taishou), magistrates (ling and zhang), and their aides (shuli), with all their entourage; ${ }^{100}$ to these categories, we can also add soldiers, doctors, architects, carpenters, and technicians. Historical records also confirm the presence of merchants, who came in pursuit of economic profit. Over the centuries, a very heterogeneous and multiethnic society

\section{Sanguozhi, v. 30, Chenhan.}

98 新羅人亦以稱樂浪, 故今本朝亦因之而稱樂浪郡夫人. Samguk Yusa, Wonder 1, Nangnang.

99 For more details, see Cho, Pŏp-jong, "Nangnanggun-ŭi sŏnggyŏk munje (The problem of the identity of the Nangnanggun)". Han'guk kodaesa yŏn'gu (Research on Korean Ancient History) 12 (2003): 167-169.

100 Byington, M. E. (edited by). The Han Commanderies in Early Korean History. Harvard: Harvard University, 2013, 105. 
arose in Nangnang, which suffused the territory with values, languages, and lifestyles that were very different from each other.

\section{Conclusions}

The presence of continental communities in Korean territory was not a new phenomenon on the Korean peninsula, but the temporal and spatial scale as well as the systematic control that characterized the settlement of Nangnang was quite unprecedented and unique. Numerous continental communities on the peninsula were part of a decentralized network, bringing in new ideas and cultural elements. Even so, Nangnang's past represents some of the most fragmentary and discontinuous parts of all of East Asian history, and its reconstruction remains a deep black hole. Nangnang was a frontier settlement, a political center within an international network: it was mainly a significantly independent and commercebased fortified city and territory, not necessarily under the coordination of a single political center.

In this article, we have approached the history of Nangnang by trying to analyze some discrepancies in the historical development of its society-an attempt to construct an alternative narrative that could explain some processes in the history of this territory from the point of view of the local people, transcending any excessively dichotomizing and atomizing approaches. The interpretation of the external presence in Nangnang territory should depart from conventional models of power, and several development processes should be seen not as an external imposition, but as a result of negotiation processes. In fact, the notion of unilateral acculturation risks obfuscating the fundamental diversity of our research questions. Behind external rulers' attempts to impose new values on and indoctrinate the local people, we find evidence of resistance on the part of the local people and elites, who did not passively accept the role of receptors of a foreign culture, but actively tried to find new opportunities in their new geopolitical context while partially maintaining their own origi- 
nal culture and values.

Beyond resisting the tendency to resort to modern colonialist frameworks, we should rely only on archaeological evidence and hope that new discoveries or disclosure of materials from North Korean scholars will allow a more detailed analysis of the reactions of local people in the Nangnang area. In the absence of records written by local and contemporaneous inhabitants of Nangnang, we may for the time being focus on some discrepancies in the course of the local culture's development, trying to find some evidence of resistance to external rule or local people's motivation to take advantage of their new circumstances. Although we are well aware of the limitations of this kind of approach, mostly due to the scarcity of primary sources, this attempt is nonetheless relevant in consideration of the sensitive nature of this chapter in East Asian history, which has been often constrained by restrictive ideological frames. However, in contrast to Wang's delineation of a long phase of Northeast Asian history known as the "Period of the Nangnang Commandery," we cannot consider this chapter of East Asian history as a whole - an era of continuity and linearity - but, on the contrary, rather as a unilinear succession of shifts and ruptures. In our attempt to reconstruct its past, we should focus more closely on discerning the tone of those changes and the signs of resistance that represent the unique voice of the local people.

\section{Bibliography}

1. Altaweel, M., and Squitieri, A. Revolutionizing a World. London : UCL Press.

2. Blagg, T., and Millet, M. The Early Roman Empire in the West. Oxford: Oxbow Books, 2002.

3. Byington, M. E. (ed.). The Han Commanderies in Early Korean History. Harvard: Harvard University, 2013.

4. Cho, In-Sung. "Chosŏn inmin yŏksa kangjwa(1950)-wa yŏksa kyoyuk-Nangnanggun-ŭi wich'i pijŏng-ŭl chungsim-ŭro" [Korean 
People's History Lecture (1950) in North Korean and History Education-Focused on the Discussion of the Location of Lelang Commandery]. Han'guk sahakpo [Journal of Korean History] 83 (May 2021): 7-28.

5. Cho, Pŏm-hwan. "Samguk Sagi Silla Pongi Ch'ogi kirog-e poi-nŭn Nangnang" [Nangnang as Seen throughout the First Records in the Silla Pongi]. Han'guk Kodaesa yŏn'gu [Research on Korean Ancient History] 1 (2009): 119-152.

6. Cho, Pŏp-jong. "Nangnanggun-ŭi sŏnggyŏk munje" [The Problem of the Identity of the Nangnanggun]. Han'guk kodaesa yŏn'gu [Research on Korean Ancient History] 12 (2003): 161-189.

7. Chōsen Sōtokufu. Rakurōgun jidai no iseki. Tokyo: Chōsen Sōtokufu, 1927.

8. Chung'ang munhwajae yŏn'guwŏn. Nangnang kokohak kaeron [Introduction to Nangnang Archaeology]. Seoul: Chininjin, 2014.

9. Cuozzo, M., \& A. Guidi. Archeologia delle identità e delle differenze. Rome: Carocci, 2013.

10. Di Cosmo, N. "Han Frontiers: Toward an Integrated View." Journal of the American Oriental Society 129, no. 2 (2009): 199-214.

11. Duncan-Jones, Richard. Structure and Scale in the Roman Economy. Cambridge: Cambridge University Press, 1990.

12. Han'guk Kokohak'oe. Han'guk kokohak kangŭi. Seoul: Sahoe p'yŏngnon, 2007.

13. Isaac, B. The Limits of Empire: The Roman Army in the East. Oxford: Clarendon Press, 1993.

14. Jung, In-seung. "Ilje kangjŏmgi-ŭi Nangnang kokohak" [Nakrang Archeology during Japanese Colonial Rule]. Han'guk sanggosa hakpo [Journal of the Korean Ancient Historical Society] 71 (2011): 149-170.

15. Kang, Chonghun. 'Samguk Sagi ch'ogi kirog-e poinŭn 'Nangnang'ŭi silch'e-Chinhan yŏnmaengch'e-ŭi kongganjŏk pŏmwi kwallyŏnhayŏ" [The Real Existence of Nangnang on the Basis of the First Account of the Samguk Sagi]. Han'guk kodaesa hakhoe [Journal of Ko- 
rean Ancient History], July 1995, 123-151.

16. Kang, Kyŏng-gu. "Nangnang ch'ilgi-ŭi munjejŏm”" [Some Questions about Nangnang Wooden Lacquerware]. Han'guk Sanggosa hakpo [Journal of the Korean Ancient Historical Society] 14 (1993): 409414.

17. Kim, Pyŏng-jun. “Chungguk kodae kandok charyo-rŭl t'ong-hae pon Nangnanggun-ŭi kunhyŏn chibae (The control of Nangnang county seen throughout ancient wooden Chinese tablets)." Yǒksa hakpo [Journal of the Korean Historical Association] 189 (2006): 139-173.

18. Kim, Nam-jung. "Sŏlmun Haeja-ŭi Ko Chosŏn-Nangnang kirokkwa chŏngŏ" [The Records of Old Chosun and Lelang in Shuowen jiezi and Their Authority]. Sŏnsa-wa Kodae [Prehistory and Ancient History] 51 (March 2017): 5-28.

19. Kim, Nam-jung. "Wiman Chosŏn-ŭi 1segi ijŏn Nangnang chiyŏk-ŭi tae-han yŏrŏ insik" [The Various Awareness for the Fall of Wiman Joseon and Nakrang Area before the First Century]. Han'guk sahakpo [Journal of Korean History] 70 (February 2018): 73-105.

20. Kwang-ŭi Ko. "Nangnanggun ch'owŏn sanyŏn hogubu chaekŏmt'o" [New Analysis of the Household Register in Nangnang Commandery in the Fourth year of Chuyuan]. Han'guk mokkan hakhoe [Wooden Document and Inscription Studies], July 2011, 15-49.

21. Komai, Kazuchika. "Rakurōgun chishi." Kōkogaku kenkyū 2. Tokyo: Kōkogaku kenkyūshitsu, 1965.

22. Kwŏn, O-jung. "Nangnanggun-ŭi sŏlch'i paegyŏng" [The Background of the Installation of Nangnanggun]. Sejong Taehak nonmunjip, 1984, 203-217.

23. Kwŏn, O-jung. "Nangnanggun-ŭi kinŭng" [The Function of Nangnanggun]. Inmun yŏn'gu, 1991, 131-149.

24. Kwŏn, O-jung. "Nangnang kujo yŏn'gu" [Study on the Structure of Nangnang]. Inmun yŏn'gu, 1988, 105-134.

25. Luley, B. P. "Cooking, Class, and Colonial Transformations in Roman Mediterranean France." American Journal of Archaeology 118, no. 1 (January 2014): 33-60. 
26. Luttwak, E. N. The Grand Strategy of the Roman Empire. Baltimore: Johns Hopkins University Press, 2016.

27. Malkin, I. A Small Greek World. Networks in the Ancient Mediterranean. Oxford: Oxford University Press, 2012.

28. Mattingly, D. J. Imperialism, Power, and Identity. Princeton: Princeton University Press, 2011.

29. Mikami Tsugio. Mansen genshi funbo no kenkyū. Tokyo: Yoshikawa kōbunkan, 1961.

30. Millett, M. The Romanization of Britain. Cambridge: Cambridge University Press, 1990.

31. Mun, An-sik. "Samguk sagi ch'ogi kirog-e poinŭn Nangnang-ŭi silch'e-e taehayŏ" [On the Real Existence of Nangnang on the Basis of the First Accounts in the Samguk Sagi]. Han'guk chónt'ong munhwa yŏn'gu [Research on Korean Traditional Culture], 2008, 194-225.

32. No, T'aedon, et al. Uri sidae-ŭi Han'guk kodaesa 1 [Ancient Korean History in Our Time]. Seoul: Churyusŏng, 2017.

33. No, T'aedon. Han'guk kodaesa [Korean Ancient History]. Seoul: Kyŏngsewŏn, 2014.

34. O, Yŏng-ch'an. Nangnanggun yŏn'gu [Study on Nangnanggun]. Seoul: Sagyejŏl, 2006.

35. Pai, Hyung Il. "Culture Contact and Culture Change: The Korean Peninsula and Its Relations with the Han Dynasty Commandery of Nangnang." World Archaeology 23, no. 3 (1992): 306-319.

36. Pai, Hyung Il. Constructing “Korean” Origins. Cambridge: HarvardHallym, 2000.

37. Pai, Hyung Il. Heritage Management in Korea and Japan: The Politics of Antiquity and Identity. Washington: University of Washington Press, 2013.

38. Pak, Sŏng-hyŏn. "Hansŏ chiriji Nangnang-gun 3su-ŭi pijŏng-e taehan kŏmt'o" [A Review of Locating Three Rivers of Lelang Commandery in the Book of Han's “Treatise on Geography”]. Han'guk kodaesa yŏn'gu [Journal of Korean Ancient History] 79 (Sept. 2015): 5-45. 
39. Park, Dae-Jae. "A New Approach to the Household Register of Lelang Commandery." International Journal of Korean History 22, no. 2 (August 2017): 5-46.

40. Park, Dae-Jae. "Nangnanggun-gwa Ko Chosŏn yumin" [The Nangnanggun and Immigrants in Ancient Chosŏn]. Nangnang kokohak kaeron. Seoul: Chininjin, 2014.

41. Said, E. Culture and Imperialism. New York: Knopf, 1993.

42. Shaw, B. D. "Rebels and Outsiders." In: The Cambridge Ancient History. Vol. 11, The Imperial Peace, A.D. 70-192, edited by S. A. Cook, F. E. Adcock, and M. P. Charlesworth. Cambridge: Cambridge University Press, 2000.

43. Song, Ho-jŏng. "Ko Chosŏn-gwa Nangnang-ŭi Pukhan munhwa yusan" [Cultural Heritage in North Korea, Ancient Chosŏn, and Nangnang]. Han'guk Kodaesa yŏn'gu [Research on Ancient Korean History] 25 , no. 3 (2002): 29-64.

44. Song, Ho-jŏng. "Hangunhyŏn chibae-ŭi yŏksa-jŏk sŏnggyŏk" [Historical Character of the Rule of Han Commanderies]. Yǒksa-wa hyŏnsil [History and Reality] 78 (2010): 38-81.

45. Son, Yŏng-jong. "Ryodong chibang Chŏ nhan Kunhyŏndŭr-ŭi wich'i-wa kŭ hu-ŭi pyŏnch'ŏn 1" [The Location of Former Han Counties in Liaodong and Changes Afterwards, 1]. Ryŏksa kwahak [Historical Science] 199 (2006): 30-33.

46. Tarpin, M. "Oppidum secondaire et agglomérations secondairs: continuités et discontinuités entre des strctures rubaines et infravicique mal définies." In: Sine iniuria in pace vivatur: A construción do Imperio durante os Xulio-Claudios, edited by Ma Dolores Dopico Caínzos and Manuel Villanueva Acuña (2020), 83-106.

47. Tesse, D. Stek. "Roman Imperialism, Globalization and Romanization in Early Roman Italy. Research Questions in Archaeology and Ancient History." Archaeological Dialogues 21, no. 1 (2014): 30-40.

48. Vergès, F. Creolization and Resistance. Creolizing Europe. Liverpool : Liverpool University Press : 38 - 55.

49. Wang, Bei Xin. Nangnang Wenhua. Beijing: Kexue chubanshe, 2007. 
50. Wang, Chong. Lunheng II. Vol. 19. Translated by Alfred Forke. New York: Paragon Book Gallery, 1962.

51. Wells, P. S. The Barbarians Speak: How the Conquered People Shaped Roman Europe. Princeton: Princeton University Press, 2001.

52. Xu, Yingzi. "Lelang Cultural Interaction Sphere: An 'Alternative' Approach to State-Formation in Korea." International Journal of Korean History 2 (December 2001): 351-361.

53. Yi, Ki-baek, and Ki-dong Yi. Han'guksa kangjwa. Iljogak: Seoul, 1982.

54. Yi, Sŏng-si. "Tong'asia-esoŭi Nangnang, Kwaje-wa pangbŏp-e taehan yŏn'gu" [Nangnang in East Asia, A Study on Tasks and Methods]. Han'guk kodaesa yŏn'gu [Research on Korean Ancient History] (June 2005): 4-19.

55. Yi, Yong-gu. 'P'yŏngyang ch'ult'o Nangnanggun ch'owŏn sanyŏn hyŏnbyŏl hogubak" [The Census by County of the Fourth Year of Chuyuan from the Nangnanggun]. Han'guk mokkan-gwa munja [Wooden Document and Inscription Studies] 3 (2009): 263-300.

56. Yun, Yong-gu. "Nangnang-gun hogubu-ŭi palgyŏn-100nyŏn Nangnang kokohak-ŭi ch'oedae suhwak" [The Finding of the Census Register of Nangnang: The Greatest Discovery in One Hundred Years of Nangnang Archaeology]. Naeil yŏnŭn yŏksa 63 (June 2016): 146162. 
$<$ Abstract $>$

\section{Discontinuities and Discrepancies in the Hybridization Process of Nangnang Culture}

This article analyses some "discrepancies" in the development of Nangnang society with a view to finding an alternative historical narrative for the territory, namely one that can explain some processes in Nangnang's history from the point of view of the local people. In the absence of any records written by contemporaneous inhabitants of Nangnang, we try to examine some discrepancies in the course of the local culture's development, aiming to glean some evidence that could be interpreted as resistance - $\mathrm{a}$ form of silent reaction to external rule. Though we are well aware of the limits of this kind of approach, mostly due to the scarcity of primary sources, this attempt is relevant in consideration of the sensitive nature of this chapter of East Asian history, which has often been constrained to narrow identities and ideological frames.

Keywords: Korea, Korean history, Nangnang, Han, Lelang 
〈국문초록〉

\section{낙랑 문화의 혼성화 및 그 불연속성과 내부균열}

Andrea de Benedittis (University of Naples “L'Orientale”)

본 논문을 통해 식민사관의 관점에서 벗어나 낙랑군의 역사를 재조명해보고자 시도 하였다. 특히 본고는 낙랑사회의 발전사서술에서 찾아볼 수 있는 몇가지 (Said가 활용 한 개념인) ‘내부균열(discrepancy)'의 현상을 분석함으로써 지역사적인 관점을 뛰어넘 고 한반도의 역사전개 과정을 설명할 수 있는 대안적인 서사방법을 모색해보고자 하였 다. 낙랑군 당대인들이 남긴 사료가 부재한 상황이기 때문에 그 지역문화의 발전과정 에서 보이는 일부 '내부균열'의 현상을 조명, 분석해보고자 하였다. 다시 말하면, 외부 의 지배자에 대한 현지인들의 '침묵적인 문화저항'(silent cultural resistance) 의 단서들 로 해석할 수 있는 일부 현상을 가려내어 분석해 보았다. 1차 사료가 부족한 상황에서 이런 식의 접근 방법에는 여러 가지 한계가 내포되어 있다는 사실을 인정할 수 밖에 없다. 그럼에도 불구하고 종종 협소한 지역정체성과 정치적인 틀로 인해 제약을 받으 며 지금까지 편파성을 잃지 못한 면이 있으며, 다소 민감하게 이해될 수도 있는 이 시 기를 동아시아적인 관점에서 좀 더 심층적으로 이해해 보고자 하였다.

주제어: 낙랑문화, 낙랑사회, 한사군, 문화저항, 혼성화 
